\title{
Faktor Penentu Kesuksesan Web-Based Appointment System di Rumah Sakit
}

\author{
Taufan Halim ${ }^{(1)}$ \\ Gede Sri Darma ${ }^{(2)}$ \\ Director of Aditama Medika Nusantara ${ }^{(1)}$ \\ Universitas Pendidikan Nasional (2) \\ halim.taufan@gmail.com ${ }^{(1)}$ \\ sridarma@undiknas.ac.id (2)
}

\begin{abstract}
Web-based appointment system (WAS) is one of digital strategy in hospital industry. It promising benefits in reducing waiting time, reducing no show rate and increasing patient's satisfaction. This competitive advantage not fully obtained because this method not fully accepted in patient's side. The aim of this study is exploring the factor that affecting patient's acceptance on WAS in hospital. This study uses a qualitative method that explores the acceptance of patient on WAS by using technology acceptance model approach. Siloam Hospital Bali was selected as the place of study since this hospital is the only hospital in Bali that use WAS and linked directly to their hospital information system. Six informants were selected using purposive, accidental and saturation sampling, divided into 3 informants who were using WAS and 3 informants who were not. Observation and in-depth interview were conducted during this study. Data is then analyzed qualitatively by data reduction, display and conclusion drawing. Data verification was performed by triangulation technic. The study shows perceived usefulness (PU) and ease of use (PEU) is the main factor that determining patient's acceptance on WAS. Three factors are identified affecting the PU and PEU. This factor are user experience, web/application and hospital responsiveness. The study shows lack of information of WAS existence is the main reason for not using it. We recommend special concern to this factor before implementing WAS. By identifying and concerning to this factor, implementation of this system will bring competitive advantage to the hospital.
\end{abstract}

Keywords: web-based appointment system; electronic appointment; hospital; bali 
Web-based Appointment System (WAS) adalah salah satu strategi digital dalam industri rumah sakit. Ini menjanjikan manfaat dalam mengurangi waktu tunggu, mengurangi tingkat no show rate dan meningkatkan kepuasan pasien. Keunggulan kompetitif ini tidak sepenuhnya diperoleh karena metode ini tidak sepenuhnya diterima di pihak pasien. Tujuan dari penelitian ini adalah mengeksplorasi faktor yang mempengaruhi penerimaan pasien pada WAS di rumah sakit. Penelitian ini menggunakan metode kualitatif yang mengeksplorasi penerimaan pasien pada WAS dengan menggunakan pendekatan technology acceptance model (TAM). Rumah Sakit Siloam Bali dipilih sebagai tempat studi karena rumah sakit ini adalah satu-satunya rumah sakit di Bali yang menggunakan WAS yang terhubung langsung ke sistem informasi rumah sakit. Enam informan dipilih menggunakan purposive, accidental dan saturation sampling, dibagi menjadi 3 informan yang menggunakan WAS dan 3 informan yang tidak. Pengamatan dan wawancara mendalam dilakukan selama penelitian ini. Data kemudian dianalisis secara kualitatif dengan reduksi data, tampilan dan penarikan kesimpulan. Verifikasi data dilakukan dengan teknik triangulasi. Studi ini menunjukkan perceived of usefulness (PU) dan perceived of ease (PEU) adalah faktor utama yang menentukan penerimaan pasien pada WAS. Tiga faktor diidentifikasi mempengaruhi PU dan PEU. Faktor ini adalah user experience, web quality dan hospital responesiveness. Studi ini menunjukkan kurangnya informasi keberadaan WAS adalah alasan utama untuk tidak menggunakannya. Kami merekomendasikan perhatian khusus untuk faktor ini sebelum menerapkan WAS. Dengan mengidentifikasi dan memperhatikan faktor ini, penerapan sistem ini akan membawa keunggulan kompetitif ke rumah sakit.

Kata kunci: web-based appointment system; electronic appointment; rumah sakit; bali 


\section{PENDAHULUAN}

Perkembangan internet dan teknologi informasi berperan penting dalam berbagai aspek kehidupan. Hal ini membawa era baru dalam seluruh industri. Rumah sakit adalah salah satu unit organisasi yang tidak lepas dari era baru ini. Teknologi informasi akan mendukung dokter, perawat dan tim multi disiplin di titik perawatan untuk memberikan kualitas layanan yang lebih baik untuk mencapai kepuasan pasien (Itumalla, 2014; Darma et. Al., 2019). Teknologi informasi berkontribusi cukup besar di dalam meningkatkan kepuasan pasien. Oleh karena itu, dapat disimpulkan bahwa pasien lebih cenderung cukup puas merasakan manfaat teknologi informasi diantaranya seperti kemudahan mendapatkan informasi, kemudahan melakukan kepengurusan administrasi, penghematan waktu tunggu baik saat pendaftaran maupun saat proses kepulangan, dan akurasi perhitungan tagihan perawatan serta ketepatan pelaporan catatan rekam medis pasien (Azhima \& Siswa, 2011). Teknologi informasi dalam dunia kesehatan telah dan terus berkembang menjadi kunci penting dalam pengalaman pasien (Werder, 2015; Darma, 2019).

Penggunaan teknologi informasi dalam kesehatan cukup luas mencakup Electronic health records, Computerized provider order entry, Decision support, Electronic results reporting, Electronic prescribing, Consumer health informatics/patient decision support, Mobile computing, Telemedicine, Electronic health communication, Administration Data exchange networks, Knowledge retrieval systems, serta teknologi informasi umum lainnya (Chaudhry et.al., 2006; Darma, 2018). WAS adalah salah satu bentuk penerapan teknologi informasi dan internet dalam dunia kesehatan.

WAS memotong alur pendaftaran pasien dengan memberikan akses kepada pasien untuk secara mandiri melakukan proses pendaftaran. Alasan utama implementasi WAS dibandingkan metode tradisional adalah biaya, fleksebilitas serta integritas (Zhao, 2017). Secara umum terdapat 2 model WAS yaitu model asynchrounise dan real time. Model asynchronise adalah pedaftaran berbasis website akan tetapi masih memerlukan administrator sebagai pernghubung anatara pasien dan sistem pendafatam. Model real time adalah model yang lebih ideal dimana pasien secara langsung terhubung ke sistem pendaftaran tempat pelayanan kesehatan (Eysenbach, 2017). WAS kemudian semakin berkembang dengan penggabungan mobile apps yang digabungkan dengan website (Ramadhani, 2016).

WAS dipercaya memberikan nilai tambah bagi pelayanan kesehatan. WAS dapat secara efektif meningkatkan kepuasan pasien dengan mendapatkan pendaftaran dan mengurangi waktu tunggu dibandingkan dengan metode pendaftaran pasien rawat jalan secara tradisional 
(Cao et. al., 2011). WAS mengurangi angka ketidakhadiran, mengurangi jumlah tenaga kerja, mengurangi waktu tunggu dan meningkatkan kepuasan (Eysenbach, 2017). WAS dan pelayanan berbasis teknologi secara positif meningkatkan kualitas pelayanan, penignkatan kualitas pelayanan memberikan efek positif terhadap kepuasan pasien (Chang \& Chang, 2008). Perubahan positif dicapai setelah mengadopsi WAS berupa penurunan no-show rate, pengurangan jumlah tenaga kerja, mengurangi waktu tunggu, dan meningkatkan kepuasan (Zao, 2017). Penggunaan WAS dapat menurunkan waktu tunggu keseluruhan serta meningkatkan kepuasan pasien dalam layanan pasien rawat jalan (Zhang, 2014).

Akan tetapi efisiensi penggunaan sistem ini masih menjadi pertanyaan. Penelitian yang sama di Taiwan menunjukkan hanya 35\% responden yang menggunakan WAS, dan $70 \%$ dari responden tersebut memilih metode walk-in dan hanya $17 \%$ memilih metode WAS untuk pendaftaran berikutnya (Zhang, 2016). Sebuah studi di Australia menunjukkan Hasil studi menunjukkan bahwa tingkat adopsi keseluruhan layanan e-appointment meningkat perlahan dari $1,5 \%$ pada 3 bulan setelah penerapan, hingga $4 \%$ pada 29 bulan, yang berarti hanya 'inovator' yang telah menggunakan layanan baru ini. Mayoritas pasien tidak mengadopsi inovasi ini (Zhang, 2015).

Berdasarkan pemaparan-pemaparan di atas, competitive advantage yang diharapkan melalui penggunaan WAS terhadap proses pendaftaran pasien rawat jalan berpotensi tidak optimal. Penelitian ini mengeksplorasi faktor-faktor apa saja yang menyebabkan pasien menggunakan serta tidak menggunakan WAS di rumah sakit. Penelitian ini bertujuan unutk membangun sebuah model konseptual. Hal ini ditujukan untuk memberikan kontribusi teori, implementasi aplikatif dalam bisnis serta kebijakan dalam implementasi.

\section{Technology Acceptance Model (TAM)}

Technology Acceptance Model (TAM) adalah teori sistem informasi yang memodelkan bagaimana pengguna menerima dan menggunakan teknologi. Model ini diawali oleh Davis (1989). Model ini menunjukkan bahwa ketika pengguna disajikan dengan teknologi baru, bagaimana keputusan mereka akan menggunakannya (Atitude toward using) dipengaruhi oleh Perceived usefulness (PU) dan Perceived Ease of use (PEOU). Perceived usefulness (PU) didefinisikan sebagai sejauh mana seseorang percaya bahwa menggunakan sistem tertentu akan meningkatkan kinerja pekerjaannya. Perceived ease of use (PEOU) didefinisikan sebagai sejauh mana seseorang percaya bahwa menggunakan sistem tertentu akan bebas dari upaya (gambar 1) (Davis, 1989)). Computer selfefficacy, objective usability, direct experience sebagai 
faktor-faktor eksternal yang mempengaruhi PU dan PEOU (Davis et all, 1989; Adnyasuari dan Darma, 2017).

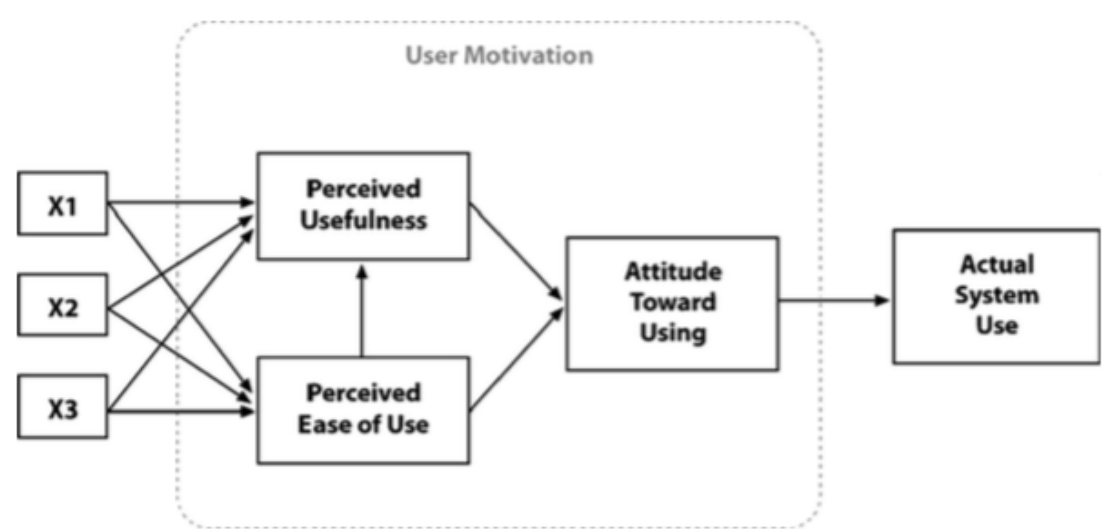

Gambar 1. Kerangka Technology Acceptance Model (TAM)

Faktor-faktor eksternal yang mempengaruhi PU dan PEOU kemudian diuji oleh banyak penelitian. Developer responsiveness mempengaruhi terhadap PU dan PEOU (Gelen \& Keti,1998)). Situational involvement, intrinsic involvement, prior use, argument of change berpengaruh terhadap PU dan PEOU (Jackson et. al., 1997). Penelitian lain menyimpulkan internal computing support, internal computing training, management support, external computing support, external computing training mempengaruhi PU dan PEOU (Igbaria, et all 1997), Role with regard to technology, tenture in workforce, level of education, prior similar experience, participation in training berpengaruh terhadap PU dan PEOU serta berpengaruh pada Attitude toward of intention penggunaan teknologi (Agarwalm \& Prasad, 1999).

Model TAM 1 disempurnakan menjadi TAM 2. TAM 2 menggambarkan beberapa faktor-faktor eksternal yang mempengaruhi PU seperti subjective norm, image, job relevance, output quality dan result demonstrability. Faktor experience dan voluntariness mejadi mediasi antara subjective norm dan PU (Davis \&Venkatesh, 2000). 


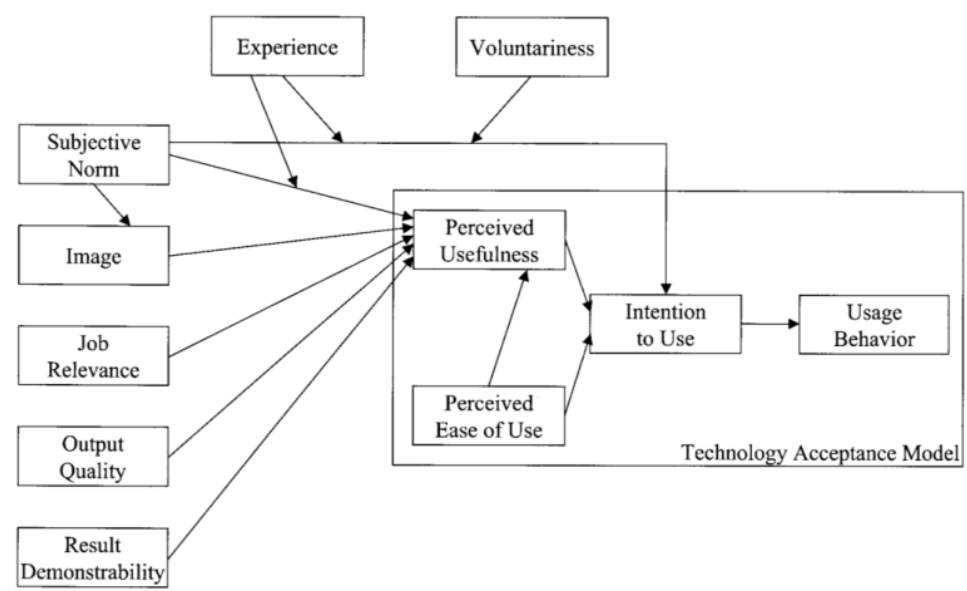

Gambar 2. Kerangka Technology Acceptance Model (TAM) 2

Penelitian tersebut menggambarkan model acceptance pekerja rumah sakit terhadap teknologi informasi dalam hal tersebut sistem informasi rumah sakit. Sementara itu, penelitan model acceptance terhadap pelayanan berbasis internet secara umum dilakukan Amerika. Behavioral intention dalam penggunaan layanan berbasis internet tersebut dipengerahui oleh provider, information-seeking preference dan internet dependence. Ketiga hal tersebut mempengaruhi behavioral intention melalui PEOU dan POU sesuai dengan TAM (Wilson \& Lankton,2004). Sebuah literature riview membahas hal serupa di Turki menjelaskan PEOU berpengaruh besar terhadap behavioral intention pasien. Sementara PEOU dipengaruhi personal norm dan perceived control belief. Kerahasiaan menjadi hal lain yang berpengaruh negative terhadap penerimaan pasien terhadap teknologi di bidang kesehatan (Gucin \& Berk, 2015).

Sebuah penelitian di Taiwan yang menggunakan TAM sebagai kerangka terhadap penerimaan pasien terhadap e-appointment. Penelitian tersebut berkesimpulan inttention of use dipengaruhi oleh PU tetapi tidak dipengaruhi oleh PEOU. Hal ini hasil yang berbeda terhadap kerangka utama TAM yang sudah diyakini sebagai model penerimaan teknologi. User experience dan web site quality sebagai faktor eksternal berpengaruh terhadap PU dan PEOU. Peniletian ini tidak menemukan pengaruh positif signifikan dari service quality terhadap PU dan PEOU (Chang et. al., 2014). 


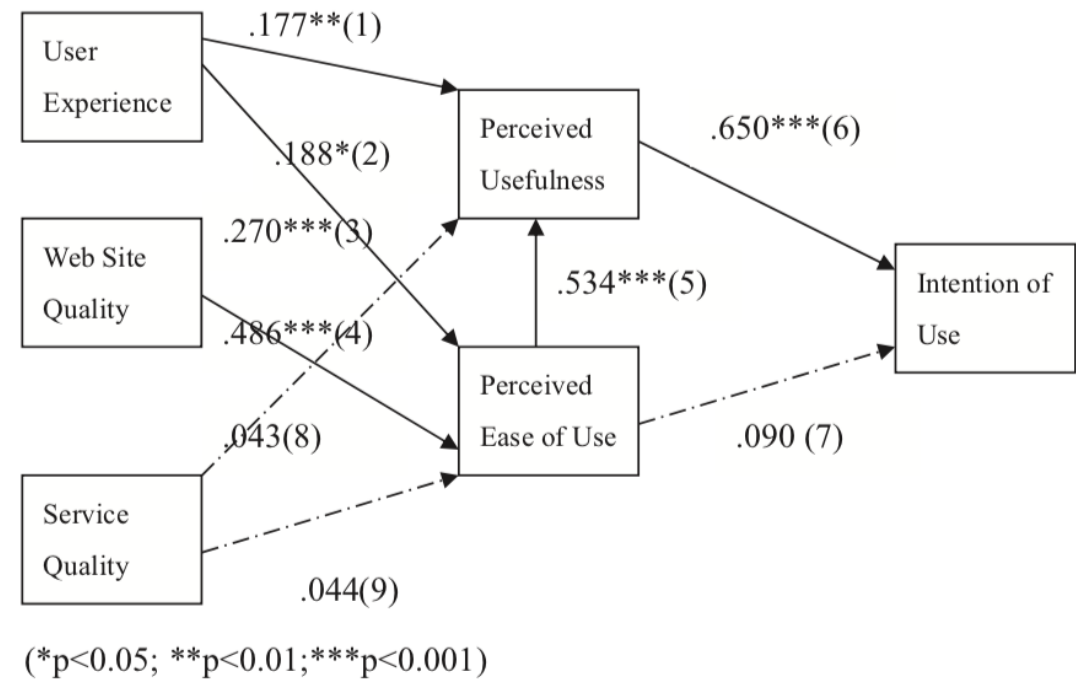

Gambar 3. Hasil Penelitian TAM penggunaan Web-Base Appointment System

Pada penelitian tersebut karakteristik pasien yang sudah banyak terpapar menggunakan internet dikatakan sebagai faktor utama penyebab hasil penelitian yang berbeda tersebut. Kemudahan tidak menjadi faktor yang mempengaruhi penggunaan WAS. Hal serupa disimpulkan oleh penelitian lain yang menyatakan technology readiness adalah determinan mayor dalam keberhasilan sistem e-appointment. Individu dengan kesiapan teknologi mendapat kepuasan yang lebih tinggi. Hal ini menjadi perhatian bagi rumah sakit dalam menentukan target pasien yang diharapkan menggunakan WAS atau e-appointment (Chen, Jong \& Lai, 2014).

Beberapa faktor berkontribusi terhadap rendahnya tingkat adopsi WAS pada pasien seperti kurangnya komunikasi tentang layanan e-appointment kepada pasien, kurangnya nilai layanan e-appointment untuk sebagian besar pasien yang dapat dengan mudah melakukan perjanjian berbasis telepon, dan keterbatasan fungsi dari layanan e-appointment, ketidakcocokan layanan baru dengan preferensi pasien untuk komunikasi lisan dengan resepsionis, dan pembatasan karakteristik pasien, berupa rendahnya tingkat pemahaman internet, kurangnya akses ke komputer atau internet di rumah, dan kurangnya pengalaman dengan layanan kesehatan online (Zhang, 2015). penerimaan pasien terhadap WAS dipengaruhi oleh pengalaman mereka terhadap komputer dan internet (Zhao, 2017). Ketidaktahuan terhadap keberadaan pendaftaran online, ketidakpercayaan terhadap internet, dan kekurangan kemampuan untuk menggunakan computer adalah alasan utama untuk tidak menggunakan Web-Base Appointment System (Cao et. al., 2011). Tidak ada pengaruh status perkawinan, pekerjaan dan penghasilan terhadap penerimaan WAS. Level Pendidikan 
kemunginan mempengaruhi penerimaan WAS. Penelitian ini menyarankan promosi dan pelayanan pelanggan dikembangkan untuk meningkatkan penerimaan pasien terhadap WAS (Zhang, et all 2014).

\section{Kerangka Konseptual}

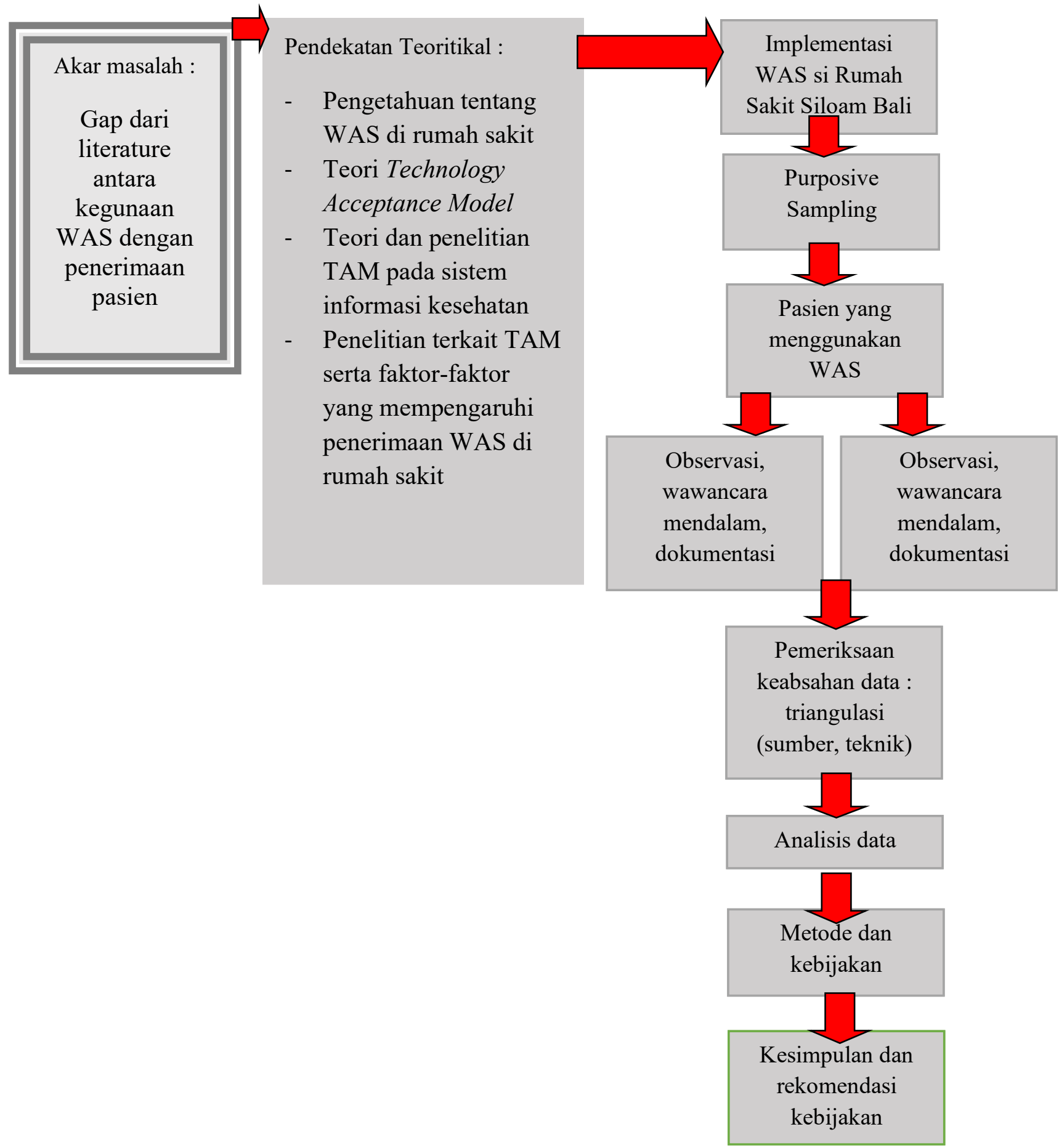

Gambar 4. Kerangka Pemikiran Penelitian 


\section{METODE PENELITIAN}

Desain penelitian yang digunakan dalam penelitian ini adalah metode kualitatif. Keterbatasan penulis yang berdomisili di Bali sehingga penelitian dilakukan terbatas di Bali. RS Siloam Bali dipilih sebagai lokasi penelitian karena satu-satunya rumah sakit di Bali yang mengimplementasikan WAS real time. Siloam Bali pada bulan Juni 2018 melakukan langkah awal penerapan aplikasi mysiloam sebagai bentuk electronic appointment pada poliklinik rawat jalan. Konsep aplikasi mysiloam ini menerapkan konsep integrasi mobile apps dan website dengan model real time berbasis cloud /komutasi awan. Proses ini diawali dengan penerapan software mysiloam dalam mengatur operasional pengaturan jadwa perjanjian oleh staff rumah sakit. Perangkat lunak ini terintegrasi dengan sistem antrian pasien di ruang praktek dokter. Perjalanan implementasinya dimulai dari internal kemudian perlahan menuju penerpanannya pada sisi pasien. Pada tahun 2019. Rumah Sakit Siloam Bali mengimplementasikan web-based appointment ini pada pasien. Penerapan proses pendaftaran rawat jalan secara elektronik ini diharapkan mampu meningkatkan kepuasan pasien dengan mengurangi waktu tunggu pasien.

Data didapat melalui observasi penulis serta wawancara terhadap informan yang telah ditentukan dengan metode purposive sampling, accidental sampling dan sampling jenuh. Informan adalag pasien yang datang minimal 2 kali dengan keluhan berbeda, tidak mengalami gangguan kejiwaan/psikiatri, serta bukan pasien pediatri (anak) Informan. Setiap satu sample pasien yang memakai WAS didampingi data dari pasien yang tidak memakai WAS. Data primer yang dicari adalah data diri pasien, user experience, web quality, hospital responsiveness, PEOU, PU dan hal-hal lain yang berkembang sejalan dengan proses wawancara. Data ekudian dianalisis secara dekriptif kualitatif dengan langkah-langkah pengumpulan, reduksi, display data dan penarikan kesimpulan.

\section{PEMBAHASAN}

\section{Perceived Usefullness}

Penulis melakukan observasi langsung dengan melakukan proses pendaftaran melalui website. Pendaftaran melalui website dilakukan melalui website www.siloamhospitals.com dengan memilih modul find a doctor, kemudian dilanjutkan dengan melakukan pemilihan terhadap lokasi Rumah Sakit, spesalisasi, nama dokter serta tanggal perjanjian yang diinginkan. Proses ini yang menghadirkan proses yang lebih cepat dIbandingkan dengan proses pendaftaran dengan telepon. Proses menelepon memakan waktu lebih dari 15 menit untuk dapat kontak dengan operator. 
Wawancara terkait PU dilakukan kepada 3 orang informan yang melakukan pendaftaran melalui WAS Hasil wawancara terhadap 3 orang tersebut adalah sebagai berikut ; Hasil wawancara Informan no.1 terkait PU

"iya berguna buat saya, bagus, daripada melalui telepon saya merasa lebih cepat"

Hasil wawancara Informan no.2 terkait PU

"berguna, karena bisa di sela-sela waktu kesibukan untuk membuat perjanjian, tidak harus menelepon atau datang langsung"

Hasil wawancara Informan no.3 terkait PU

"iya berguna, lebih cepat, daripada menelpon susah masuk"

Wawancara terkait PU terhadap informan yang tidak melakukan pendaftaran melalui WAS tidak dapat dievaluasi karena informan tidak mengetahui keberadaan proses pendaftaran melalui WAS sehingga tidak mempunyai pengalaman dalam memakai metode pendaftaran tersebut.

\section{Perceived ease of use}

Peneliti melakukan observasi langsung dengan melakukan proses pendaftaran melalui website. Pendaftaran melalui website dilakukan melalui website www.siloamhospitals.com dengan memilih modul find a doctor, kemudian dilanjutkan dengan melakukan pemilihan terhadap lokasi Rumah Sakit, spesalisasi, dokter serta tanggal perjanjian yang diinginkan. Proses ini mudah serta tidak membingungkan.

Wawancara terkait PEU dilakukan kepada 3 orang informan yang melakukan pendaftaran melalui WAS. Hasil wawancara terhadap 3 orang tersebut adalah sebagai berikut; Hasil wawancara Informan no. 1 terkait PEU

"ya saya merasa cukup mudah, langsung bisa"

Hasil wawancara Informan no. 2 terkait PEU

“cukup mudah dan informatif, langsung terdapat informasi nama dokter dan jadwal praktek yang kosong” 
Hasil wawancara Informan no.3 terkait PEU

"proses pendaftaran melalui dari website gampang, hanya perlu mengisi"

Wawancara terkait PEU terhadap informan yang tidak melakukan pendaftaran melalui WAS tidak dapat dievaluasi karena informan tidak mengetahui keberadaan proses pendaftaran melalui WAS sehingga tidak mempunyai pengalaman dalam memakai metode pendaftaran tersebut.

\section{User Experience}

Wawancara terkait user experience dilakukan kepada 3 orang informan yang melakukan pendaftaran melalui WAS. Hasil wawancara terhadap 3 orang tersebut adalah sebagai berikut

Hasil wawancara Informan no.1 terkait user experience

"ya, saya setiap hari memakai internet, saya tidak pernah memakai jenis appointment seperti ini sebelumnya"

Hasil wawancara Informan no.2 terkait user experience

"iya, saya memakai internet setiap hari. saya belum pernah memakai sistem seperti ini sebelumnya biasanya menelpon langsung kamudian bertanya ketersediaan dokter dan waktu perjanjiannya"

Hasil wawancara Informan no.3 terkait user experience

"iya saya cukup sering memakai internet, saya tidak pernah memakai sistem seperti ini sebelumnya"

Wawancara terkait user experience terhadap informan yang tidak melakukan pendaftaran melalui WAS tidak dapat dievaluasi karena informan tidak mengetahui keberadaan proses pendaftaran melalui WAS sehingga tidak mempunyai pengalaman dalam memakai metode pendaftaran tersebut.

\section{Web / Application Quality}

Wawancara terkait Web / Application Quality dilakukan kepada 3 orang informan yang melakukan pendaftaran melalui WAS. Hasil wawancara terhadap 3 orang tersebut adalah sebagai berikut ; 
Hasil wawancara Informan no.1 terkait Web / Application Quality

"websitenya responsive dengan handphone dan cukup cepat"

Hasil wawancara Informan no.2 terkait Web / Application Quality

"ya websitenya cukup simple dan memudahkan"

Hasil wawancara Informan no.3 terkait Web / Application Quality

"websitenya simple dan mudah dimengerti, apa yang diminta tinggal diisi"

Wawancara terkait Web / Application Quality terhadap informan yang tidak melakukan pendaftaran melalui WAS tidak dapat dievaluasi karena informan tidak mengetahui keberadaan proses pendaftaran melalui WAS sehingga tidak mempunyai pengalaman dalam memakai metode pendaftaran tersebut.

\section{Hospital Responsiveness}

Wawancara terkait Hospital Responsiveness dilakukan kepada 3 orang informan yang melakukan pendaftaran melalui WAS. Hasil wawancara terhadap 3 orang tersebut adalah sebagai berikut :

Hasil wawancara Informan no.1 terkait Hospital Responsiveness

"saya mencari dokter kulit melalui webite dan saya melihat bisa appointment langsung jadi saya langsung appointment. Akan lebih baik jika ada konfirmasi langsung melalui email untuk kepastian mendapat perjanjian. Saya tidak mendapat email notifikasi”

Hasil wawancara Informan no.2 terkait Hospital Responsiveness

"saya cek di google, kemudian masuk di website dan langsung memakai, saya tadi mengalami kendala dan saya harus menelpon sendiri untuk kendala saya tersebut"

Hasil wawancara Informan no.3 terkait Hospital Responsiveness

"awalnya saya browsing di internet, dan ternyata bisa daftar online. Saya tidak mendapat konfirmasi lebih lanjut melalui email. Saya tidak paham ini berhasil atau tidak. Mungkin lain kali bisa diberikan email konfirmasi jika sudah berhasil”"

Wawancara terkait Hospital responsiveness terhadap informan yang tidak melakukan pendaftaran melalui WAS menunjukkan ketidaktahuan informan terhadap keberadaan metode pendaftaran model ini. 
Hasil wawancara Informan no.1

"tidak, saya tidak tahu bisa daftar melalui website"

Hasil wawancara Informan no.2

"tidak, saya biasanya lewat front office. Saya tidak tahu bisa lewat aplikasi"

Hasil wawancara Informan no.3

"tidak, saya biasanya lewat front office. Saya tidak tahu ad acara lain. mungkin bisa saya coba. Kalua memang lebih cepat mengapa tidak"

\section{PEMBAHASAN}

\section{Perceived Usefullness dan Ease of us}

Pada penelitian ini, ketiga informan mengatakan merasa WAS memberikan kegunaan berupa lebih cepat daripada metode perjanjian dengan telepon. Ketiga informan juga menyebutkan menyatakan WAS mudah digunakan. Ketiga informan menyatakan cukup mengisi data sesuai dengan kebutuhan informan dan tidak menemukan kesulitan dalam penggunaan WAS. Hasil observasi peneliti juga menemukan kecepatan perjanjian dengan WAS dibandingkan dengan melakukan perjanjian dengan telepon. Perjanjian dengan telepon memakan waktu lebih dari 15 menit untuk berhubungan dengan operator. Hal observasi peneliti juga menemukan WAS mudah digunakan dengan mengisi kolom sesuai kebutuhan peneliti dalam mencari pelayanan kesehatan. Technology Acceptance Model yang dikemukakan oleh Davis (1989) dimama behavior intention penggunaan teknologi baru dipengaruhi oleh PU dan PEU sejalan dengan temuan pada penelitian ini. Hasil penelitian ini juga tetap sejalan dengan penelitian lain dari Gelen \& Keti (1998), Jackson, et. al. (1997), Igbaria, et. al. (1997), Ahwarwalm \& Prasad (1990), Davis \& Vanekatesh (2000), Anggelidis \& Chatzoglou (2008), Wilson \& Lankton (2004), Gucin \& Berk (2015), Adnyasuari \& Darma (2017), Hendhana \& Darma (2017) juga mendukung technology accaptence model ini dimana behavior intention penggunaan teknologi baru dipengaruhi oleh persepsi pengguna terhadap kemudahan dan kegunaan teknologi tersebut. Penelitian Chang et. al. (2014) mengemukakan terdapat hubungan yang signifikan $P U$ terhadap intention of use dari WAS akan tetapi tidak menemukan hubungan signifikan PEU terhadap penggunaan WAS. Hal tersebut tidak senada dengan penemuan penelitian ini. Ketiga informan mengatakan merasa mudah dalam pemakaian WAS ini. 


\section{User experience}

Ketiga informan dalam penelitian ini menyatakan bahwa setiap hari menggunakan internet serta tidak pernah menggunakan sistem perjanjian serupa sebelumnya. Penelitian ini menemukan user experience terhadap internet adalah faktor eksternal yang mempengaruhi PU dan PEU dalam penggunaan WAS di rumah sakit. Hal ini sejalan dengan penelitian dari Chang et. al. (2014), Setyawati \& Darma (2018) dan Zhao (2017). Zhang et all (2014) juga menyatakan tidak ada pengaruh status perkawinan, pekerjaan dan penghasilan terhadap penerimaan WAS. Hal tersebut senada dengan penelitian ini dimana ketiga informan memiliki karakteristik yang berbeda. Penelitian ini juga menemukan pengalaman penggunaan webbased appointment sebelumnya tidak memengaruhi penggunaan WAS. PU dan PEU dipengaruhi oleh user experience terhadap komputer dan internet sebelumnya.

\section{Web / Application Quality}

Ketiga informan menyatakan WAS yang digunakan cepat, simple, serta responsive dalam penggunaan perangkat mobile. Hasil observasi peneliti juga menemukan WAS yang digunakan cepat, simple serta responsive dalam penggunaan mobile. Penelitian ini menemukan hal serupa dengan Chang, et. al. (2014) dimana web / application quality mempengaruhi penggunaan WAS melalui PEU dan PU.

\section{Hospital Responsiveness}

Pada penelitian ini menemukan hospital responsiveness mempengaruhi penggunaa WAS. Ketiga informan menyatakan kurangnya notifikasi keberhasilan perjanjian mereka dalam bentuk digital maupun non-digital. Pernyataan tersebut dinyatakan secara konsisten oleh ketiga informan. Hal ini berbeda dengan penelitian Chang, et. al. (2014) dimana tidak menemukan hubungan signifikan hospital responsiveness terhadap PEU dan PU. Penelitian ini menemukan peran manusia dalam menjembatani teknologi dan manusia tetap diperlukan khususnya dalam menghadapi kendala dalam penggunaan teknologi. Hospital Responsiveness akan mempengaruhi PEU dan PU dari pengguna sehingga mempengaruhi penggunaan WAS.

\section{Ketidaktahuan terhadap keberadaan WAS}

Penulis menemukan tidaktahuan terhadap keberadaan metode perjanjian web-based appointment sytem merupakan penyebab utama pasien tidak menggunakan WAS. Seluruh informan mengungkapkan bahwa tidak tahu proses perjanjian dapat diakukan melalui website serta aplikasi sehingga tetap melakukan proses pendaftaran melalui telepon. Hal ini senada dengan penelitian dari Cao, Wenjun, et. al. (2011) dimana lebih dari 50\% responden 
menyatakan ketidaktahuan terhadap keberadaan WAS. Hal lain yang diungkap Cao, Wenjun, et. al. (2011) berupa ketidakpercayaan terhadap internet serta kurang nya literasi terhadap computer dan internet tidak terungkap dalam penelitian ini.

\section{PENUTUP}

Dari penelitian yang telah dilakukan, dapat disimpulkan faktor yang mempengaruhi penggunaan WAS di rumah sakit adalah PU dan PEU sesuai dengan teori technology acceptance model. Faktor-faktor eksternal yang mempengaruhi kedua hal tersebut adalah user experience, web / application quality dan hospital responsiveness. Faktor yang menyebabkan pasien tidak menggunakan WAS di rumah sakit yang terungkap pada penelitian ini adalah ketidaktahuan terhadap keberadaan WAS. Implementasi WAS harus mengedepankan kegunaan serta kemudahan bagi pasien. Implementasi WAS juga harus memandang 3 foktor yang mempengaruhi PU dan PEU yakni user experience, web / application quality serta hospital responsiveness. Implementasi WAS pada target pasien yang menggunakan internet pada kehidupan sehari-hari. mengedepankan web / application quality. mempersiapkan tim rumah sakit dalam menanggulangi kendala penggunaan oleh pasien. Penyebaran informasi keberadaan WAS juga harus dipersiapkan sehingga menjadi lebih diterima. Peneliti menyadari dengan keterbatasan yang dimiliki oleh peneliti. Penelitian lebih lanjut diharapkan dapat dilakukan pada beberapa tempat lokasi yang berbeda. Hal ini untuk memperkaya karakteristik informan serta jumlah data yang lebih banyak. Penelitian selanjutnya juga sebaiknya dilakukan pada informan yang sudah terpapar WAS akan tetapi kembali mengggunakan metode perjanjian lama. Hal ini untuk dapat memperbandingkan serta mengevaluasi lebih dalam terhadap faktor-faktor yang menyebabkan pasien menggunakan metode perjanjian ini. 


\section{DAFTAR PUSTAKA}

Adnyasuari, P.A.S., and Darma, G.S. (2017). Technology Acceptance Model dan ESatisfaction in Mobile Banking, Jurnal Manajemen \& Bisnis, 14 (2): 1-12.

Agarwal, R., Prasad, J. (1997). The Role Of Innovation Characteristics And Perceived Voluntariness In The Acceptance Of Information Technology, Decision Sciences, 28 (3), dalam https://onlinelibrary.wiley.com/doi/abs/10.1111/j.15405915.1997.tb01322.x diakses 15 Juli 2018.

Agarwal, R., Prasad, J. (1999). Are Individual Differences Germane To Acceptance Of New Information Echnology ?, Decision Sciences, $30 \quad$ (2), dalam https://onlinelibrary.wiley.com/doi/abs/10.1111/j.1540-5915.1999.tb01614.x, diakses 15 Juli 2018.

Aggelidis, VP., Chatzoglou PD. (2008). Using A Modified Technology Acceptance Model In Hospital, International Journal of Medical Information, 78: 115,126, dalam https://www.ncbi.nlm.nih.gov/pubmed/18675583, diakses 16 Jui 2018.

Cao, Wenjun, et all, (2011). A web-based appointment system to reduce waiting for outpatients: A retrospective study”, BMC Health Services Research, 11 (318). dalam http://www.biomedcentral.com/1472-6963/11/318, diakases pada 2 Juli 2018.

Chang, HH, Chang, CS, (2008). An Assesment of Technology-Based Service Encounter \& Network security on The E-Health Care System of Medical Ceners in Taiwan, $B M C$ Health Services Research, 8:87, dalam http://www.biomedcentral.com/14726963/8/87, diakses pada 2 Juli 2018.

Chang, Mong-Yuan, et all. (2014). Exploring User Acceptance of An E-Hospital Service: An Empirical Study In Taiwan”, computer Standards \& Interfaces 38, 35 (43), dalam https://www.sciencedirect.com/science/article/pii/S0920548914000828, diakses pada 2 Juli 2018.

Chang, Mong-Yuan, et all. (2014). Exploring User Acceptance of An E-Hospital Service: An Empirical Study In Taiwan, computer Standards \& Interfaces 38, 35 (43), dalam https://www.sciencedirect.com/science/article/pii/S0920548914000828, diakses pada 2 Juli 2018.

Chaudhry, Basit et all. (2006). Systematic Review: Impact of Health Information Technology on Quality, Efficiency, and Costs of Medical Care, Annals of Internal Medicine, 144 (10), dalam, https://www.ncbi.nlm.nih.gov/pubmed/16702590, diakses pada tanggal 2 Juli 2018. 
Chen, Shih-Chih., Jong, Din., Lai, Min-Tsai. (2014). Assessing the Relationship between Technology Readiness and Continuance Intention in an E-Appointment System: Relationship Quality as a Mediator, $J$ Med Syst, 38 (76), dalam https://www.ncbi.nlm.nih.gov/pubmed/25007955, diakses 2 Juli 2018.

Darma, G.S. (2019). Kacamata Media, Kesuksesan Bersyarat. Indonesia: Pustaka Larasan Press.

Darma, G.S., Apollo, A., Rusmanda, G., and Umar, Y. (2019). Digital Education 4.0. Indonesia: Cakra Media Utama Press.

Darma, G.S. (2018). Seuntai Pesan, Menjawab Zaman. Indonesia: Pustaka Larasan Press.

Darma, G.S. (2006). Manajemen Strategi: Solusi dalam Dunia Nir Kabel. Denpasar: Undiknas Press.

Darma, G.S. (2005). Teknologi Informasi, Kepuasan User, Kinerja User dan Kinerja Hotel di Bali, Jurnal Ekonomi \& Bisnis, 17 (2): 93-102.

Darma, G.S. (1999). Information Technology and Organisational Performance: A Study of the Hospitality Industry, Southern Cross University, Lismore New South Wales Australia. Davis, et all. (1989). User Acceptance of Computer Technology : A Comparison of Two Theoretical Model, Management Science, 35 (8), dalam https://www.researchgate.net/profile/...Bagozzi/...User_Acceptance_of_Computer_Te c. , diakses pada 15 Juli 2018.

Davis, F.D., Venkatesh, V. (2000). Atheoretical Extension of Technology Acceptance Model: Four Longitudinal Field Studies, Management Science, 46 (2): 186-204.

Davis, F.D. (1989). Perceived Usefulness, Perceived Ease of Use and User Acceptance of Information Technology, MIS Quarterly, 13 (3): 319-340.

Gelen, D., Keli, M. (1998). The Impact of Developer Responsiveness On Perception of Usefulness and Ease of Use: An Extension of Technology Acceptance Model, The Database for Advances In Information System, 29 (2), dalam https://dl.acm.org/citation.cfm?id=298757, diakses pada 15 Juli 018.

Gucin, NO., Berk, OS, (2015). Technologycal Acceptance In Health Care: An Intehrative Review of Predictive Factorand Intervening Programs, Procedia-social and behavioral, 195: 1698-1704, dalam https://core.ac.uk/download/pdf/82610233.pdf , diakases 16 Juli 2018.

Hendhana, S., and Darma, G.S. (2017). Service Quality Rumah Sakit dan Efeknya terhadap Patient Satisfaction, Perceived Value, Trust, dan Behavioral Intention, Jurnal 
Manajemen \& Bisnis, 14 (1): 37-55.

Igbaria, et all. (1997). Personal Computing Acceptance Factor In Small Firm: A Structural Equation Model, MIS Quarterly, dalam https://pdfs.semanticscholar.org/e527/95e3c977e1d6e585b86c78ab10e1bfa6a867.pdf, diakses pada 15 Juli 2018.

Itumalla, R. (2012). Information Technology and Service Quality in Health Care: An Empirical Study of Private Hospital in India, International Journal of Innovation, Management and Technology, 3 (4), August 2012, dalam, www.ijimt.org/papers/269-CM248.pdf , diakses pada 2 Juli 2018.

Jackson, et all, (1997). Toward An Understanding Of Behavioral Intention To Use An Information System, Decision Scince, $\mathbf{2 8} \quad$ (2), dalam https://onlinelibrary.wiley.com/doi/abs/10.1111/j.1540-5915.1997.tb01315.x , diakses pada 14 Juli 2018.

Matthew, W. (2015). Health Information Technology: A Key Ingredients of The Pastient Experience, Patient Experience Journal, 2 (1), Article 19, dalam, $\mathrm{h}$ p://pxjournal.org/journal/vol2/iss1/19, diakses pada, 2 Juli 2018.

Ramadhani, E. (2016). E-Health Design : Integrasi E-Appointment berbasis android dan website. disampaikan dalam Seminar Nasional Art Sains Dan Teknologi (SNATS) 1 201623 November 2016.

Setyawati, T., and Darma, G.S. (2018). Efektifkah Experiential Marketing di Sebuah Rumah Sakit ?, Jurnal Manajemen \& Bisnis, 15 (1): 160-175.

Wilson, EV., Lankton, NK. (2004). Modeling patients acceptance of provider-delivered Ehealth, Journal of The American Medical Informatics Association, 11 (4), dalam https://www.ncbi.nlm.nih.gov/pmc/articles/PMC436070/ . diakses 16 Juli 2018.

Yoga, T.A. (2011). Peranan Teknologi Informasi dan Kualitas Layanan Terhadap Kepuasan Pasien Rawat Inap (Studi Pada PT. Perkebunan Nusantara XI Persero Rumah Sakit LAVALETTE Malang), Magister Manajemen Pascasarjana Fakultas Ekonomi, Universitas Brawijaya, Malang.

Zhang, X. (2015). Using Diffusion of Innovation Theory to Understand The Factors Impacting Patient Acceptance and Use of Consumer E-Health Innovations: A Case Study In A Primary Care Clinic, BMC Health Service Research, 15 (71), dalam https://bmchealthservres.biomedcentral.com/articles/10.1186/s12913-015-0726-2, diakses 2 Juli 2018. 
Zhang, M, et all. (2014). Questionnaire Survey About Use of An Online Appointment Booking System In One Large Tertiary Public Hospital Outpatient Service Center In China, BMC Medical Informatics and Decision Making, 14 (49), dalam http://www.biomedcentral.com/1472-6947/14/49, diakses pada 2 Juli 2018.

Zhao P, et all. (2017). Web-Based Medical Appointment Systems: A Systematic Review, Journal of Medical Internet Research, $\mathbf{2 6} \quad$ (04), dalam https://www.ncbi.nlm.nih.gov/pubmed/28446422\#, diakses pada 2 Juli 2018. 